\title{
Pengaruh Gaya Kepemimpinan Dan Motivasi Terhadap Burnout Pada PT. Indaco Warna Dunia (Regional Sales Purwokerto)
}

\author{
Alif Fajri Husaeni \\ Master of Accounting Study Program Faculty of Economic, Jenderal Soedirman University \\ aliffajri.husaeni@gmail.com \\ Adi Wiratno \\ Master of Accounting Study Program Faculty of Economic, Jenderal Soedirman University
}

\begin{abstract}
Abstrak
Tujuan dari penelitian ini adalah untuk mengetahui apakah gaya kepemimpinan dan motivasi berpengaruh terhadap burnout pada karyawan. Dari paparan teoritis maka dapat dirumuskan hipotesis bahwa ada pengaruh gaya kepemimpinan terhadap burnout, dan ada pengaruh motivasi terhadap burnout pada karyawan. Populasi dalam penelitian ini adalah seluruh karyawan di PT. Indaco Warna Dunia (Regional Sales Purwokerto). Teknik pengambilan sampel yang digunakan adalah purposive sampling. Data penelitian menggunakan data primer berupa kuesioner dengan menggunakan 50 responden. Hasil penelitian ini menunjukan bahwa gaya kepemimpinan mempengaruhi keinginan burnout. Semakin baik gaya kepemimpinan suatu perusahaan maka akan semakin rendah karyawan terhadap burnout. Motivasi juga memiliki pengaruh negatif terhadap burnout.
\end{abstract}

Kata Kunci : Gaya kepemimpinan, Motivasi, Burnout

\section{The Influence Of Leadership Style And Motivation On Burnout In PT. Indaco Warna Dunia (Regional Sales Purwokerto)}

\begin{abstract}
The purpose of this research is to find out whether leadership and motivation styles affect the burnout of employees. From the theoretical exposure then it can be formulated hypothesized that there is a leadership style influence against burnout, and there is a motivation influence against burnout in employees. The population in this study is all employees at PT. Indaco Warna Dunia (Regional Sales Purwokerto). Sampling techniques used are purposive sampling. Research data uses primary data in the form of questionnaires using 50 respondents. The results of this study showed that the leadership style influenced the desire of burnout. The better the leadership style of a company then the lower the employee will be against the burnout. Motivation also has a negative influence on burnout.
\end{abstract}

Keywords : Leadership style, motivation, burnout

\section{PENDAHULUAN}

Dalam peradaban manusia sekarang ini segala aspek kehidupan tidak lepas dari berorganisasi, karena pada kodratnya manusia merupakan makhluk sosial yang cenderung untuk selalu hidup bermasyarakat. Hal ini nampak baik didalam kehidupan rumah tangga, organisasi kemasyarakatan, terlebih pada saat seseorang memasuki dunia kerja. Seseorang tersebut akan berinteraksi, dan masuk menjadi bagian dalam organisasi tempatnya bekerja. Organisasi adalah unit sosial yang dengan sengaja dikelola, terdiri atas dua orangatau lebih, yang berfungsi secara relative terus-menerus untuk mencapai satu sasaran atau serangkaian sasaran bersama (Robbins, 2006).

Dalam mencapai tujuan organisasi, setiap organisasi memerlukan sumber daya untuk mencapainya.Sumber daya itu antara lain sumber daya alam, sumber daya finansial, sumber daya ilmu pengetahuan dan teknologi, serta sumber daya manusia. Diantara sumberdaya tersebut, sumberdaya yang terpenting ialah sumberdaya manusia. 
Sumberdaya manusia merupakan aset organisasi yang paling penting, dan membuat sumberdaya organisasi lainnya menjadi bekerja (Simamora, 2006). Dengan demikian, tanpa sumberdaya manusia sumberdaya lainnya akan menganggur dan kurang bermanfaat dalam mencapai tujuan organisasi.

Dalam mencapai tujuan organisasi, karyawan hal yang perlu di perhatikan adalah stress kerja karyawan atau biasa di sebut dengan burnout. Freudenberg, (dalam Hera, 2016) menyatakan bahwa burnout adalah suatu bentuk kelelahan yang disebabkan karena seseorang yang bekerja terlalu intens, berdedikasi, dan berkomitmen, bekerja terlalu banyak dan terlalu lama serta memandang kebutuhan dan keinginan mereka sebagai hal kedua. Hal ini menyebabkan individu tersebut merasakan tekanan-tekanan yang dapat memberikan dampak kurang baik bagi tubuh individu itu sendiri juga produktifitas kerja dengan prevalensi kejadian yang terus meningkat sehingga memerlukan perhatian serius dari para pemangku kepentingan Yang pada mulanya berasal dari gaya kepemimpinan.

Seorang pemimpin harus menerapkan gaya kepemimpinan untuk mengelola bawahannya, karena seorang pemimpin akan sangat mempengaruhi keberhasilan organisasi dalam mencapai tujuannya. Gaya kepemimpinan adalah perilaku atau cara yang dipilih dan dipergunakan pemimpin dalam mempengaruhi pikiran, perasaan, sikap dan perilaku para anggota organisasi bawahannya (Nawawi, 2003:115).

PT. Indaco Warna Dunia,Tbk dalam jangka waktu tertentu, Pemimpin dalam tiap unit-unit perusahaan selalu dilakukan rolling jabatan, dimana setiap pemimpin memiliki gaya kepemimpinan berbeda. Dimana setiap gaya kepemimpinan memiliki dampak positif maupun negatif atas kinerja karyawan. Aspek burnout atau kejenuhan karyawan juga menjadi aspek penting dalam kinerja karyawan dimana dalam jaman globalisasi sekarang ini tentunya kebutuhan setiap karyawan akan semakin bertambah seiring perkembangan jaman.

Dengan melihat dan memperhatikan uraian-uraian tersebut diatas, sehingga penulis tertarik mengambil judul: "Pengaruh Gaya Kepemimpinan dan Motivasi terhadap Kinerja Karyawan Pada PT. Indaco Warna Dunia (Regional Sales Purwokerto).

\section{TINJAUAN PUSTAKA}

\section{Gaya Kepemimpinan}

Menurut Thoha (2013:49) bahwa Gaya Kepemimpinan merupakan norma perilaku yang digunakan oleh seseorang pada saat orang tersebut mencoba mempengaruhi perilaku orang lain seperti yang ia lihat. Hasibuan (2016:171) mengemukakan 3 dimensi gaya kepemimpinan yaitu:

1. Kepemimpinan Otoriter

2. Wewenang mutlak terpusat pada pimpinan

3. Keputusan selalu dibuat oleh pimpinan

4. Tidak ada kesempatan bagi bawahan untuk memberikan saran

5. Kepemimpinan Delegatif

6. Pimpinan melimpahkan wewenang lebih banyak kepada bawahan

7. Keputusan lebih banyak dibuat oleh para bawahan

8. Bawahan bebas menyampaikan saran dan pendapa

9. Kepemimpinan Partisipatif

10. Wewenang pimpinan tidak mutlak

11. Keputusan dibuat bersama antara pimpinan dan bawahan

12. Banyak kesempatan bagi bawahan untuk menyampaikan saran dan pendapat.

\section{Motivasi}

Dalam kehidupan berorganisasi, pemberian dorongan sebagai bentuk motivasi kerja kepada bawahan penting dilakukan untuk meningkatkan kinerja karyawan. Menurut Malayu (2005: 143), motivasi berasal dari kata latin movere yang berarti dorongan atau pemberian daya penggerak yang menciptakan kegairahan kerja seseorang agar mereka mau bekerja sama, bekerja efektif, dan terintegrasi dengan segala daya upayanya untuk mencapai kepuasan. Motivasi merupakan factor yang kehadirannya dapat menimbulkan kepuasan kerja, dan meningkatkan kinerja karyawan (Umar,1999). Kemudian Siagian (2002) mengatakan bahwa dalam kehidupan berorganisasi, termasuk kehidupan berkarya dalam organisasi, aspek motivasi kerja mutlak mendapat perhatian serius dari para pemimpin yang setiap hari berkontak langsung dengan bawahan di tempat kerja.

Motivasi sendiri adalah reaksi yang timbul dari dalam diri seseorang sebagai dorongan karena adanya rangsangan dari luar yang mempengaruhi untuk memenuhi tujuan tertentu (Suranta,2002). 
Berdasarkan pengertian tentang motivasi diatas, disimpulkan bahwa motivasi kerja adalah dorongan atau semangat yang timbul dalam diri seseorang atau karyawan untuk melakukan sesuatu atau bekerja, karena adanya rangsangan dari luar baik itu dari atasan serta adanya dasar untuk memenuhi kebutuhan dan rasa puas, serta memenuhi tanggung jawab atas tugas-tugas yang diberikan dan dilakukan dalam organisasi. Teori McClelland (Robins, 2006) mengatakan 3 poin, yaitu:

1. Kebutuhan akan prestasi: Dorongan untuk mengungguli, berprestasi sehubungan dengan seperangkat standar, bergulat untuk sukses.

2. Kebutuhan akan kekuasaan: kebutuhan untuk membuat orang lain berperilaku dalam suatu cara yang orang-orang itu [tanpa dipaksa] tidak akan berperilaku demikian.

3. Kebutuhan akan afiliasi: hasrat untuk hubungan antar-pribadi yang ramah dan akrab.

\section{Burnout}

Istilah burnout pertama kali dikemukakan oleh Freudenberger, seorang ahli psikologi klinis yang sangat familiar dengan respon stres yang di tunjukan oleh para staf yang melayani masyarakat, pada tahun 1974, burnout merupakan representasi dari sindrom pschycological stress yang menunjukkan respon negatif sebagai hasil dari tekanan pekerjaan (Cordes \& Dougherty,1993). Pekerja yang mengalami burnout menjadi berkurang energi dan ketertarikannya pada pekerjaan. Selanjutnya, beberapa peneliti melihat burnout sebagai bagian dari stres (Luthans, 2006).

Menurut Kreitner dan Kinicki (1992) burnout adalah akibat dari stres yang berkepanjangan dan terjadi ketika seseorang mulai mempertanyakan nilai-nilai pribadinya. Burnout adalah kondisi di mana seseorang kehilangan energi psikis maupun fisik. Biasanya hal itu disebabkan oleh situasi kerja yang tidak mendukung atau tidak sesuai dengan kebutuhan dan harapan. Biasanya burnout dialami dalam bentuk kelelahan fisik, mental, dan emosional yang intens. Kekurang jelasan hak dan tanggung jawab kerja serta konflik peran (misalnya tuntutan kerja tidak konsisten dengan nilai-nilai yang diyakini) dapat berkontribusi. Salah satu persoalan yang muncul berkaitan dengan diri individu di dalam menghadapi tuntutan organisasi yang semakin tinggi dan persaingan yang keras di tempat kerja karyawan itu adalah stres.

Definisi lain dikemukakan oleh Maslach dan Goldberg (1998) yang menjelaskan burnout sebagai sindrom kelelahan emosional, depersonalisasi, dan penghargaan yang rendah terhadap diri (low personal accomplishment). Sedangkan Pines dan Aroson mendefinisikan burnout sebagai suatu keadaan kelelahan secara fisik, emosi dan mental yang disebabkan keterlibatan dalam jangka waktu yang panjang pada situasi yang secara emosional penuh dengan tuntutan (Pines \& Aroson, dalam Cooper et al,1996). Dari beberapa definisi di atas, jadi dapat disimpulkan bahwa burnout merupakan perubahan sikap dan perilaku dalam bentuk menarik diri secara psikologis dari pekerjaan, merasa tidak berdaya, merasa tidak ada harapan, merasa terjebak kesedihan yang mendalam secara terus menerus menimbulkan rasa lelah dan ketidakberdayaan, merasa kekurangan energi untuk bekerja, bersikap kasar terhadap orang lain dan tidak peduli dengan lingkungan sekitar. Menurut Caputo (1991) timbulnya burnout disebabkan oleh beberapa faktor yang di antaranya yaitu :

a. Karakteristik Individu

Sumber dari dalam diri individu merupakan salah satu penyebab timbulnya burnout. Sumber tersebut dapat digolongkan atas dua faktor yaitu :

Faktor demografi, mengacu pada perbedaan jenis kelamin antara wanita dan pria. Pria rentan terhadap stress dan burnout jika dibandingkan dengan wanita. Orang berkesimpulan bahwa wanita lebih lentur jika dibandingkan dengan pria, karena dipersiapkan dengan lebih baik atau secara emosional lebih mampu menangani tekanan yang besar (Farber, 1991). Tetapi menurut Maslach (dalam Sutjipto, 2001) menemukan bahwa pria yang burnout cenderung mengalami depersonalisasi sedangkan wanita yang burnout cenderung mengalami kelelahan emosional.

b. Faktor perfeksionis

Individu yang selalu berusaha melakukan pekerjaan sampai sangat sempurna sehingga akan sangat mudah merasakan rustrasi bila kebutuhan untuk tampil sempurna tidak tercapai. Karena, menurut Caputo (1991) individu yang perfeksionis rentan terhadap burnout.

c. Lingkungan kerja

Lingkungan kerja dapat menentukan kemungkinan munculnya burnout seperti beban kerja yang berlebihan, konflik peran, jumlah individu yang harus dilayani, tanggung jawab yang harus dipikul, pekerjaan rutin dan yang bukan rutin, ambiguitas peran, dukungan sosial dari rekan kerja yang tidak memadai, dukungan sosial dari atasan tidak memadai, kontrol yang rendah terhadap pekerjaan dan kurangnya stimulasi dalam pekerjaan. 
Lingkungan kerja terbagi menjadi 2 yaitu lingkungan kerja fisik dan lingkungan kerja non fisik. Lingkungan kerja fisik menurut Sedarmayanti (2009) yaitu semua keadaan berbentuk fisik yang terdapat di sekitar tempat kerja dimana dapat mempengaruhi karyawan baik secara langsung maupun tidak langsung, sedangkan lingkungan kerja non fisik adalah semua keadaan yang terjadi yang berkaitan dengan hubungan kerja, baik hubungan dengan atasan maupun hubungan sesama rekan kerja, ataupun hubungan dengan bawahan. Ditambahkan Sentoso (2001) lingkungan kerja non fisik merupakan lingkungan kerja yang dapat membangun suatu iklim dan suasana kerja yang bisa membangkitkan rasa kekeluargaan untuk mencapai tujuan bersama.

d. Keterlibatan emosional

Penerimaan pelayanan atau pelanggan, bekerja melayani orang lain membutuhkan banyak energi karena harus bersikap sabar dan memahami orang lain dalam keadaan krisis, frustrasi, ketakutan dan kesakitan. Pemberi dan penerima pelayanan turut membentuk dan mengarahkan terjadinya hubungan yang melibatkan emosional, dan secara tidak sengaja dapat menyebabkan stres secara emosional kerena keterlibatan antar mereka dapat memberikan penguatan positif atau kepuasan bagi kedua belah pihak, atau sebaliknya.

\section{Pengaruh Gaya Kepemimpinan Terhadap Burnout}

Ketika karyawan diperlakukan dengan cara yang adil dan hormat oleh pimpinan, mereka cenderung memikirkan hubungan dengan pimpinan dalam hal pertukaran sosial daripada pertukaran ekonomi (Blau, 1964). Selanjutnya, mereka cenderung melakukan tindakan balasan dengan memberikan usaha ekstra ke dalam pekerjaan atau dedikasi terhadap pekerjaan yang lebih banyak (Brown et al., 2005) dan bersedia untuk menjadi lebih banyak terlibat dalam pekerjaan (Macey et al., 2009).

Gaya Kepemimpinan merupakan bagian penting dari manajemen, sebagaimana pernyataan Bennis (Yukl, 2010) bahwa "Managers are people who do things right and leaders are people who do the right thing". Pendapat ini mendefinisikan pemimpin sebagai orang yang dapat menentukan secara benar apa yang harus dikerjakan dan manajer adalah orang yang dapat mengerjakan secara benar semua tugas dan tanggung jawabnya. Berdasarkan uraian di atas dapat disajikan hipotesis sebagai berikut :

H1 : Gaya kepemimpinan memiliki pengaruh positif terhadap burnout

\section{Pengaruh Motivasi terhadap Burnout}

Motivasi kerja adalah dorongan atau semangat yang timbul dalam diri seseorang atau karyawan untuk melakukan sesuatu atau bekerja, karena adanya rangsangan dari luar baik itu dari atasan serta adanya dasar untuk memenuhi kebutuhan dan rasa puas, serta memenuhi tanggung jawab atas tugas-tugas yang diberikan dan dilakukan dalam organisasi.

Dampak negatif yang mempengaruhi karyawan sendiri dan perusahaan dapat diminimalkan, sehingga motivasi kerja diperlukan, yaitu sebagai sesuatu yang menciptakan antusiasme atau motivasi kerja yang akan menentukan ukuran pencapaian atau kinerja yang dicapai. Dalam penelitian sebelumnya, masih ada kontroversi tentang hasil yang menunjukkan bahwa hubungan antara variabel penelitian seperti yang dalam penelitian ternyata memiliki efek positif dan ada efek negatif seperti yang dilakukan oleh Romli (2010) dari penelitiannya yang menyatakan bahwa variabel kerja stres memiliki efek positif dan signifikan pada motivasi kerja berbeda dari yang dilakukan oleh Adraeni (2003) dari penelitiannya yang menyatakan bahwa variabel kerja stres tidak secara signifikan mempengaruhi motivasi kerja. Selain itu, kepemimpinan pada stres kerja adalah penelitian yang dilakukan oleh Hamdani (2012) dari penelitiannya menyatakan bahwa variabel kepemimpinan berpengaruh negatif pada stres kerja terbalik penelitian yang dilakukan oleh Leonita (2013) dari penelitian menyatakan bahwa kepemimpinan variabel berpengaruh negatif signifikan stres kerja. Dari uraian tersebut dapat disajikan hipotesis sebagai berikut.

H2 : Motivasi memiliki pengaruh positif terhadap burnout 


\section{Kerangka Pemikiran}

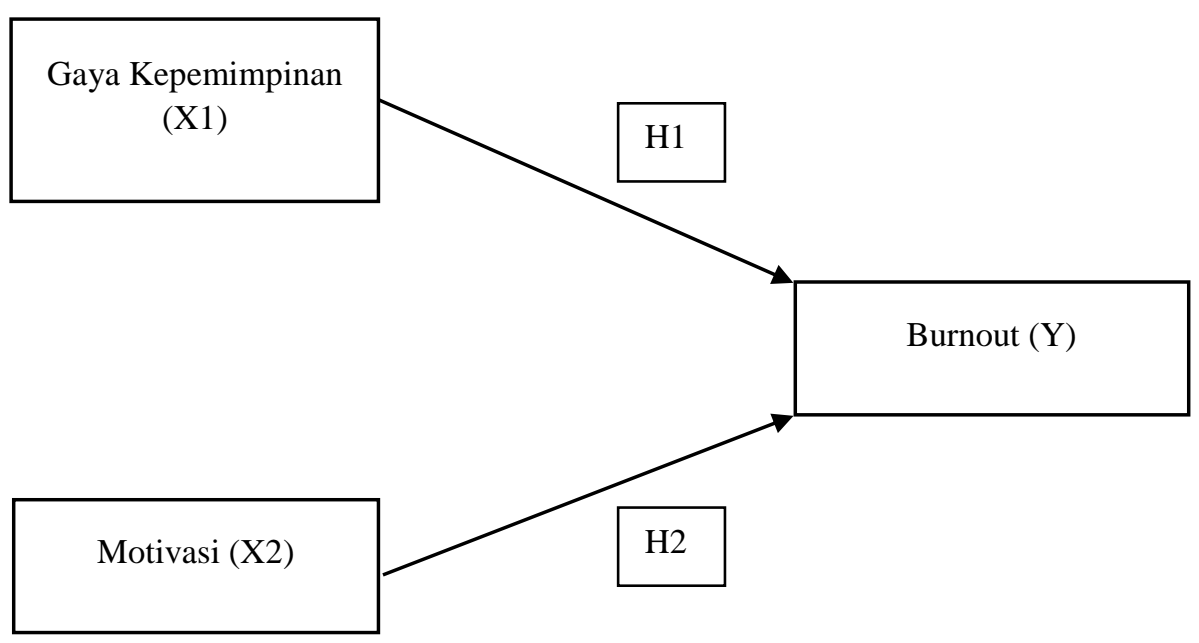

Gambar 1. Kerangka Pemikiran

\section{METODE PENELITIAN}

\section{Desain Penelitian}

Jenis penelitian yang dilakukan adalah penelitian kuantitatif dengan analisis regresi logistik yang mencari pengaruh antara variabel bebas (independen) dengan variabel terikat (dependen). Sugiyono, (2012:8) penelitian kuantitatif yaitu metode penelitian yang berlandaskan pada filsafat positivisme, digunakan untuk meneliti pada populasi atau sampel tertentu, pengumpulan data menggunakan instrumen penelitian, analisis data bersifat kuantitatif/statistik, dengan tujuan untuk menguji hipotesis yang telah ditetapkan.

\section{Populasi dan Sampel Penelitian}

Populasi untuk penelitian ini adalah seluruh karyawan PT. Indaco Warna Dunia ( Regional Sales Purwokerto). Dalam pengambilan sampel cara probabilitas besarnya peluang atau probabilitas elemen populasi untuk terpilih sebagai subjek diketahui. Sedangkan dalam pengambilan sampel dengan cara nonprobability besarnya peluang elemen untuk ditentukan sebagai sampel tidak diketahui. Uma (2006) mengatakan bahwa desain pengambilan sampel dengan cara probabilitas jika representasi sampel adalah penting dalam rangka generalisasi lebih luas.

Bila waktu atau faktor lainnya, dan masalah generalisasi tidak diperlukan, maka cara nonprobability biasanya yang digunakan.

Maka dalam penelitian ini peneliti menggunakan teknik non-probability sampling yang didalamnya dilakukan dengan teknik convenience sampling. Convenience sampling menurut (Uma, 2006) adalah sebagai kumpulan informasi dari anggota-anggota populasi yang mudah diperoleh dan mampu menyediakan informasi tersebut. Dengan demikian siapa saja yang dapat memberikan informasi baik secara tidak sengaja atau kebetulan bertemu dengan peneliti, dapat digunakan sebagai sampel, bila dilihat orang yang memberikan informasi-informasi tersebut cocok sebagai sumber data.

\section{Sumber dan Teknik Pengumpulan Data}

Data yang akan diambil dalam penelitian ini adalah berupa data primer sedangkan metode pengumpulan data dilakukan dengan kuisioner tertutup yang diberikan kepada responden secara langsung (Sugiyono, 2013:135).

\section{Metode Anlisis Uji Instrumen Penelitian}

Validitas instrumen dalam penelitian ini diuji dengan cara menghitung korelasi Pearson dari skor tiap item pertanyaan dengan skor totalnya. Sedangkan untuk reliabilitas menggunakan Alpha Chronbach $>0,60$. 


\section{Teknik Analisis Data dan Pengujian Hipotesis}

Teknik analisis data dalam penelitian ini menggunakan analisis regresi logistik. Analisis regresi logistik digunakan jika asumsi multivariate normal distribution tidak terpenuhi karena variabel independen merupakan campuran antara variabel kontinyu (metrik) dan kategorial (non-metrik) (Hartono, 2013).

Dalam perhitungan pengolahan data, peneliti mempergunakan alat bantu yang berupa program aplikasi komputer yaitu SPSS versi 21.0 dengan melakukan analisis deskriptif dan analisis regresi logistik Pengujian hipotesis dilakukan dengan uji signifikansi simultan (Uji F), uji signifikansi parameter individual (uji t), uji koefisiensi determinasi (uji $R^{2}$ ), dan uji koefisiensi determinasi parsial (uji $r^{2}$ ).

Uji Validitas

Husein Umar dalam Sugiyono (2013:178) menyatakan bahwa validitas menunjukan derajat ketepatan antara data yang sesungguhnya terjadi pada objek dengan data yang dikelompokan.Uji validitas digunakan untuk melihat tiap item dalam instrument valid atau tidak. Dalam penelitian ini seluruh indikator dari variabel gaya kepemimpinan dan komitmen organisasi dinyatakan valid karena memiliki nilai di atas 0.30 yang artinya instrument penelitian dapat digunakan.

\section{Uji Reliabilitas}

Uji Reliabilitas digunakan untuk melihat apakah instrumen penelitian dapat digunakan lebih dari satu kali, paling tidak oleh responden yang sama (Umar, 2013:54). Hasil uji reliabilitas untuk variabel gaya kepemimpinan dan motivasi masing-masing memiliki nilai Cronbach's Alpha 0.000 dan 0.000. karena nilai Cronbach's Alpha > 0.60 maka sebagaimana dasar pengambilan keputusan dalam uji reliabilitas, dapat disimpulkan bahwa semua item dari variabel gaya kepemimpinan dan motivasi adalah reliabel atau konsisten. Uji Normalitas

Uji normalitas bertujuan untuk mengetahui apakah dalam model regresi, variabel pengganggu atau residual memiliki distribusi normal (Ghozali, 2016:154). Uji normalitas dapat dilakukan dengan analisis statistik menggunakan nilai kolmogorov-smirnov menggunakan SPSS IBM Statistic 24

\section{Uji Multikolinearitas}

Uji multikolinearitas dilakukan untuk mengetahui apakah dalam model regresi ditemukan adanya korelasi antara variabel dependen dan independen. Model regresi yang baik seharusnya tidak terjadi korelasi antara variabel dependen dan independen (Ghozali, 2013:105).

\section{Uji Heteroskedastisitas}

Uji heteroskedastisitas dilakukan untuk mengetahui apakah dalam model regresi terjadi ketidaksamaan varians dari residual suatu pengamatan ke pengamatan lain. Jika varians dari residual suatu pengamatan ke pengamatan lain tetap, namun dikatakan homoskedastisitas, jika varians berbeda dikatakann heteroskedastisitas. Model regresi yang baik adalah yang mengalami heteroskedastisitas (Umar, 2013:82).

\section{Uji Hipotesis}

\section{Uji Hosmer and Lemeshow's Goodness of Fit}

Uji Hosmer and Lemeshow's Goodness of Fit menguji hipotesis nol bahwa data empiris cocok atau sesuai dengan model atau tidak ada perbedaan antara model dengan data sehingga model dapat dikatakan fit. Pengujian kelayakan model regresi logistik dilakukan dengan menggunakan Goodness of fit test yang diukur dengan nilai Chi-Square pada bagian bawah uji Homser and Lemeshow.

\section{HASIL DAN PEMBAHASAN}

Karakteristik responden berdasarkan umur, untuk responden dengan umur 20-25 tahun berjumlah 10 orang atau 20\% dari total responden, responden dengan umur 26-35 tahun berjumlah 28 orang atau 56\% dari total responden, responden dengan umur 36-45 tahun berjumlah 8 orang atau $16 \%$ dari total responden, dan responden dengan umur $>46$ tahun hanya berjumlah 4 responden atau $8 \%$ dari total responden.

Hasil penelitian yang dilakukan di PT Indaco Warna Dunia (Regional Sales Purwokerto) menunjukan bahwa terdapat dua jabatan kerja yaitu karyawan tetap dan kontrak. Untuk karyawan tetap berjumlah 28 responden atau $56 \%$ dari total reponden, sedangkan untuk karyawan kontrak berjumlah 22 responden atau $44 \%$ dari total responden.

Berdasarkan karakteristik lama bekerja reponden diperoleh hasil responden yang sudah bekerja selama 1 tahun berjumlah 12 atau 24\% dari total responden, respond dengan masa kerja 2 tahun berjumlah 8 atau 16\% 
dari total responden, responden yang sudah bekerja selama 3 tahun berjumlah 6 atau $12 \%$ dari total reponden, responden dengan masa kerja 4 tahun berjumlah 4 atau $8 \%$ dari total responden, sedangkan responden dengan masa kerja $>5$ tahun berjumlah 20 atau $40 \%$ dari total responden.

\section{Burnot}

Berdasarkan penelitian yang di lakukan di PT. Indaco Warna Dunia (Regional Sales Purwokerto) diperoleh hasil 33 responden atau 66\% dari total reponden tidak mengalami burnout sedangkan 17 atau 34\% dari total responden mengalami burnout.

\section{Uji Normalitas}

Tabel 1. Uji Normalitas One-Sample-Kolmogorov Smirnov Test

\section{One-Sample Kolmogorov-Smirnov Test}

Unstandardiz

ed Residual

\begin{tabular}{llr}
\hline N & & 50 \\
\hline Normal Parameters $^{\mathrm{a}, \mathrm{b}}$ & Mean & .0000000 \\
\cline { 2 - 3 } & Std. Deviation & .38509171 \\
\hline Most Extreme & Absolute & .119 \\
\cline { 2 - 3 } Differences & Positive & .119 \\
\cline { 2 - 3 } & Negative & -.094 \\
\hline Test Statistic & & .119 \\
\hline Asymp. Sig. (2-tailed) & & $.075^{\mathrm{c}}$ \\
\hline
\end{tabular}

a. Test distribution is Normal.

b. Calculated from data.

Sumber : Data Penelitian Tahun 2020

c. Lilliefors Significance Correction.

Berdasarkan tabel normalitas tersebut, besarnya nilai Kormogorov-Smirnov dengan keinginan berpindah kerja sebagai variabel dependen adalah 0.094 dan signifikansi pada 0.075 yang nilainya diatas 0,05. Sehingga dapat dikatakan bahwa data residual dengan burnout sebagai variabel dependen berdistribusi normal.

\section{Uji Multikolinearitas}

Tabel 2. Uji Multikolinearitas

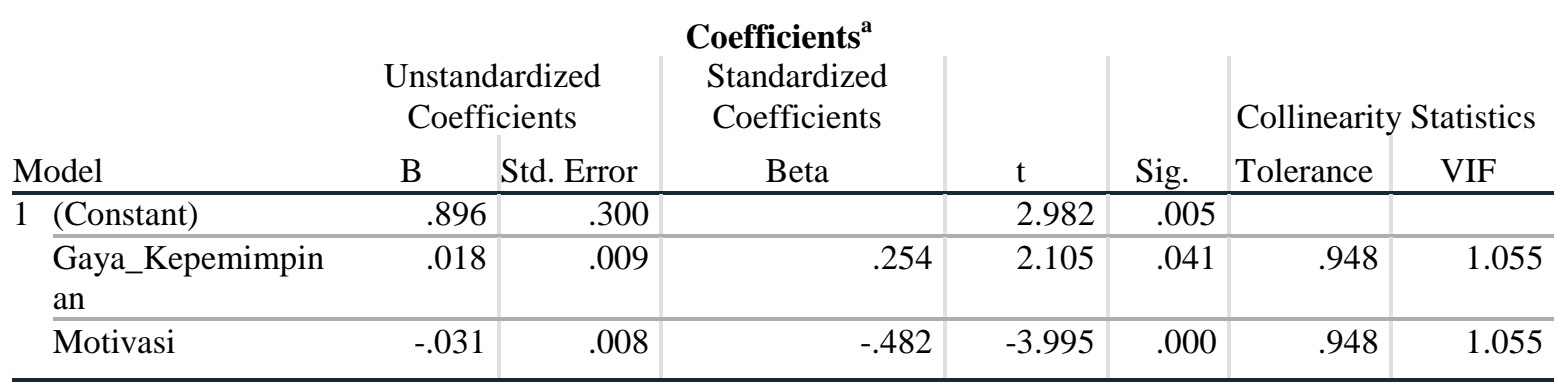

a. Dependent Variable: Burnout

Sumber : Data Penelitian Tahun 2020

Dari hasil output multikolinearitas dengan residual burnout sebagai variabel dependen dapat diketahui bahwa nilai tolerance untuk gaya kepemimpinan dan motivasi masing-masing sebesar 0.948 an 0.948. Sedangkan nilai VIF untuk gaya kepemimpinan dan komitmen organisasi masing-masing sebesar 1.055 dan 1.055. Berdasarkan tabel terlihat bahwa semua variabel bebas mempunyai nilai tolerance lebih dari 0,1 dan nilai VIF kurang dari 10. Jadi dapat dikatakan bahwa tidak ada multikolinieritas antar variabel bebas pada model regresi. 


\section{Uji Heteroskedastisitas}

Tabel 3. Uji Heteroskedastisitas

\begin{tabular}{|c|c|c|c|c|c|}
\hline \multirow[b]{3}{*}{ Model } & \multicolumn{2}{|c|}{ Coefficients $^{a}$} & \multirow{3}{*}{$\begin{array}{c}\text { Standardized } \\
\text { Coefficients } \\
\text { Beta }\end{array}$} & \multirow[b]{3}{*}{$\mathrm{t}$} & \multirow[b]{3}{*}{ Sig. } \\
\hline & \multicolumn{2}{|c|}{$\begin{array}{l}\text { Unstandardized } \\
\text { Coefficients }\end{array}$} & & & \\
\hline & $\mathrm{B}$ & Std. Error & & & \\
\hline 1 (Constant) & .466 & .178 & & 2.612 & .012 \\
\hline Gaya_Kepemimpinan & -.003 & .005 & -.093 & -.624 & .536 \\
\hline Motivasi & -.004 & .005 & -.118 & -.797 & .430 \\
\hline
\end{tabular}

Sumber : Data Penelitian Tahun 2020

Dari output Uji Glejser pada tabel 1.2 dengan residual burnout sebagai variabel dependen dapat diketahui bahwa nilai signifikansi untuk gaya kepemimpinan dan motivasi masing-masing sebesar 0.536 dan 0.430. Karena nilai signifikansi masing-masing lebih besar dari 0,05 maka dapat disimpulkan bahwa tidak ada heteroskedastisitas dalam model regresi dengan burnout sebagai variabel dependen.

Uji Hosmer and Lemeshow's Goodness of Fit

Tabel 4. Uji Hosmer and Lemeshow's Goodness of Fit

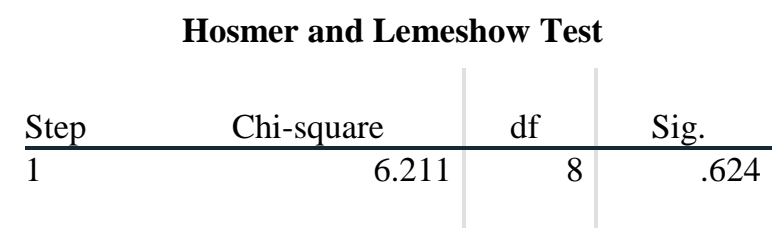

Sumber : Data Penelitian Tahun 2020

Nilai statistik Hosmer and Lemeshow's Goodness of fit sebesar 6,211 dengan 8 df dan probabilitas signifikansi sebesar 0,624. Nilai probabilitas siginifikansi lebih besar dari $\alpha=5 \%$ atau 0,05 , maka model regresi logistik yang digunakan dalam penelitian dapat diterima (Saraswati, 2019), maka hal tersebut dapat menggambarkan hubungan antara gaya kepemimpinan dan motivasi dengan burnout.

\section{Uji Nilai -2 Log Likelihood}

Uji -2 Log Likelihood pada menunjukkan nilai -2 Log Likelihood pada awal (Blok Number $=0$ ) sebesar 64,110 dan -2 Log Likelihood pada akhir (Blok Number =1) sebesar 41,842. Dengan demikian terjadi penurunan angka -2 Log Likelihood sebesar 22,268 yang menunjukkan model regresi baik atau fit.

\section{Uji Koefisien Determinasi (Nagelkerke's R Square)}

\section{Tabel 5. Uji Koefisien Determinasi}

\begin{tabular}{lc|c|c}
\multicolumn{4}{c}{ Model Summary } \\
Step & $\begin{array}{c}-2 \text { Log } \\
\text { likelihood }\end{array}$ & $\begin{array}{c}\text { Cox \& Snell } \\
\text { R Square }\end{array}$ & $\begin{array}{c}\text { Nagelkerke R } \\
\text { Square }\end{array}$ \\
\hline 1 & $41.842^{\text {a }}$ & .359 & .497 \\
\hline \multicolumn{4}{c}{ a. Estimation terminated at iteration number 6} \\
because parameter estimates changed by less than \\
,001.
\end{tabular}

Sumber : Data Penelitian Tahun 2020

Nilai Cox Snell'R Square sebesar 0,359 dan nilai Nagelkerke's R Square adalah 0,497 atau 50\%. Hal ini menunjukkan bahwa variabel-variabel independen dalam penelitian ini dapat menjelaskan variabel burnout sebesar 50\% sedangkan sisanya 50\% dapat dijelaskan oleh faktor-faktor lain diluar model penelitian ini. 


\section{Pengujian Hipotesis}

Tabel 6. Hasil Uji Regresi Logistik

\begin{tabular}{lll|r|r|r|r|r|}
\multicolumn{7}{c}{ Variables in the Equation } \\
& & B & S.E. & Wald & df & Sig. & Exp(B) \\
\hline $\begin{array}{l}\text { Step } \\
1^{\text {a }}\end{array}$ & Gaya_Kepemimpinan & .114 & .064 & 3.138 & 1 & .038 & 1.120 \\
\cline { 2 - 8 } & Motivasi & -.194 & .067 & 8.508 & 1 & .004 & .823 \\
\hline Constant & & & & & & \\
\hline
\end{tabular}

a. Variable(s) entered on step 1: Gaya_Kepemimpinan, Motivasi.

Berdasarkan informasi pada tabel 1.8 diperoleh persamaan sebagai berikut :

$\operatorname{Logit}\left(\frac{\pi}{1-\pi}\right)=2.628+0.114-0.194+€$

Koefisien B1 = 0.114 (positif) dan Exp B1 = 1.120, artinya karyawan yang merasakan gaya kepemimpinan yang baik maka karyawan tidak mengalami burnout sebesar 1.120 kali dibandingkan karyawan yang merasakan gaya kepemimpinan yang buruk. Oleh karena nilai B1 positif, maka gaya kepemimpinan mempunyai hubungan positif terhadap burnout. Variabel gaya kepemimpinan memiliki nilai signifikan sebesar 0.038. Nilai tersebut lebih kecil dari tingkat alpha yaitu 0.05 sehingga dapat diinterpretasikan bahwa variabel gaya kepemimpinan memiliki pengaruh terhadap burnout. Maka, hipotesis pertama (H1) dalam penelitian ini diterima.

Koefisien B2=-0.194 (negatif) dan $\operatorname{Exp}(\mathrm{B}) 2=0.823$, artinya semakin tinggi motivasi karyawan maka mengalami burnout semakin rendah 0.823 kali. Oleh karena B2 bernilai negatif, maka motivasi memiliki hubungan negatif terhadap burnout. Variabel motivasi memiliki nilai signifikan 0.004. Nilai tersebut lebih kecil dari tingkat alpha yaitu 0.05 sehingga dapat diinterpretasikan bahwa variabel motivasi memiliki pengaruh terhadap burnout. Maka hipotesis kedua (H2) dalam penelitian ini diterima.

\section{KESIMPULAN}

Berdasarkan hasil penelitian mengenai pengaruh gaya kepemimpinan dan motivasi terhadap burnout dapat disimpulkan bahwa gaya kepemimpinan memiliki pengaruh positif terhadap burnout, dan komitmen organisasi memiliki pengaruh negatif terhadap keinginan berpindah kerja.

Hasil pengujian secara empiris membuktikan bahwa gaya kepemimpinan otoriter memiliki pengaruh positif terhadap burnout. Dengan demikian, seorang pemimpin hendaknya menerapkan gaya kepemimpinan yang baik sehingga membuat karyawan merasa nyaman berada dalam perusahaan dan karyawan tidak merasakan burnout.

Hasil pengujian secara empiris juga membuktikan motivasi memiliki pengaruh negatif terhadap burnout. Hal tersebut berarti jika seorang karyawan memiliki motivasi yang kuat pada perusahaan maka dia akan merasa bertanggungjawab pada perusahaan dan akan melakukan pekerjaan semaksimal mungkin bukan hanya untuk kepentingan pribadi namun juga untuk kepentingan organisasi atau perusahaan. Begitupun sebaliknya jika seorang karyawan tidak memiliki motivasi yang besar pada diri mereka maka karyawan tersebut akan merasa burnout.

Hasil penelitian tersebut sejalan dengan teori pertukaran sosial (Social Exchange) dimana seorang individu cenderung memikirkan hubungan dengan pimpinan dalam hal pertukaran sosial daripada pertukaran ekonomi. Jika seorang karyawan diperlakukan baik oleh pimpinan maka dia akan melakukan tindakan balasan dengan memberikan pekerjaan atau dedikasi terhadap pekerjaan yang lebih banyak. 


\section{DAFTAR PUSTAKA}

Sukmana, Endri, and Gede Adyana Sudibia. "Pengaruh Kepemimpinan Transformasional, Motivasi Dan Burnout Terhadap Kinerja Karyawan Outsourcing Rri Mataram." E-Jurnal Manajemen 4.8 (2015).

REZA, Rregina Aditya, and I. Dirgantara. Pengaruh gaya kepemimpinan, motivasi dan disiplin kerja terhadap kinerja karyawan PT Sinar Santosa Perkasa Banjarnegara. Diss. Universitas Diponegoro, 2010.

Tampi, Bryan Johannes. "Pengaruh Gaya Kepemimpinan dan Motivasi terrhadap Kinerja karyawan pada PT. Bank Negara Indonesia, tbk (regional sales manado)." ACTA DIURNA KOMUNIKASI 3.4 (2014).

Risambessy, Agusthina, et al. "Pengaruh Gaya Kepemimpinan Transformasional, Motivasi, Burnout Terhadap Kepuasan Kerja dan Kinerja Karyawan." Jurnal Aplikasi Manajemen 9.3 (2011): 840-851.

Mahendra, Kadek Manik Oko, and Ni Wayan Mujiati. "Pengaruh Kepemimpinan Transformasional, Disiplin Kerja, Dan Burnout Pada Kinerja Karyawan Arma Museum and Resort." E-jurnal Manajemen 4.10 (2015).

Bahar, Inta Nilya. "Hubungan antara gaya kepemimpinan Atasan otoriter dengan burnout." (2008).

Katarini, Nikki Rasuna. "Burnout Pada Karyawan Ditinjau Dari Persepsi Budaya Organisasi dan Motivasi Intrinsik di PT. Krakatau Steel." (2011).

Ghozali, I. (2013). Aplikasi Analisis Multivariate dengan Program IBM SPSS. Semarang: Badan Penerbit Universitas.

Hasibuan, M. S. (2016). Manajemen Sumber Daya Manusia. Edisi. Jakarta: Penerbit PT Bumi Aksara.

Jogiyanto, H. (2013). Metodologi Penelitian Bisnis Salah Kaprah dan Pengalaman-pengalaman. Yogyakarta: Edisi 5. BPFE-Yogyakarta.

Sugiyono. (2013). Metode Penelitian Kuantitatif Kualitatif dan R \& D. Bandung: Alfabeta.

Thoha, M. (2013). Kepemimpinan Dalam Manajemen. Jakarta: T. Raja Grafindo Persada.

Uma, Sekaran. 2006. Research Methods For Business (Metode Penelitian untuk Bisnis). Edisi empat buku 1. Salemba Empat.

Umar, H. (2013). Metode Penelitian untuk Skripsi dan Tesis. Jakarta: Rajawali.

Yukl, G. (2010). Kepemimpinan Organisasi. Jakarta: Edisi Kelima, PT Indeks. 